Journal of Food and Nutritional Sciences Research 2019, 1(1), 12-17.

\title{
Effect of Some Processing Methods on Nutrient Content and Anti-Nutritional Factors of a Variety of Dolichos Lablab (Lablab Purpureus L.) Beans Grown in Kenya
}

\author{
${ }^{*}$ Sheila M. Kilonzi ${ }^{1,2}$, Anselimo O. Makokha, ${ }^{2}$ Glaston M. Kenji ${ }^{2}$ \\ ${ }^{1}$ Department of Food Science and Nutrition, School of Agriculture and Biotechnology, Karatina University, \\ P.O. Box 1957- 10101, Karatina, Kenya skilonzi@gmail.com \\ ${ }^{2}$ Department of Food Science and Technology, Faculty of Agriculture, Jomo Kenyatta University of Agricul- \\ ture and Technology, P.O. Box 62000-00200, Nairobi, Kenya \\ anmakokha@gmail.com, mwakenji@agric.jkuat.ac.ke \\ *Corresponding author: Sheila M. Kilonzi: skilonzi@gmail.com . \\ https://doi.org/10.37512/500
}

\begin{abstract}
This study aimed to determine the effect of different processing methods on the proximate composition and anti-nutritional factors of Dolichos lablab beans (Lablab purpureus) of Kenya. The seeds of KAT/DL-2 variety,sourced from Kenya Agricultural Livestock and Research Organisation, Katumani Dryland Research Station were sorted, then subjected to different processing methods (soaking, cooking and germination). The samples were analysed for proximate composition, tannins, phytates and trypsin inhibitory activity. The results showed a significant increase $(2.0 \%)$ in crude protein content for germinated lablab beans while carbohydrates content was high in cooked samples. The variety KAT/DL-2 had high levels of phytates; $723.6 \mathrm{mg} / 100 \mathrm{~g}$ and tannins $330.3 \mathrm{mg} / 100 \mathrm{~g}$ and trypsin inhibitor activity $1.3 \mathrm{mg} / 100 \mathrm{~g}$. Cooking achieved the highest reduction of anti-nutrients with $88 \%$ reduction in TIU. The results revealed that the anti-nutrients in lablab beans can be reduced using different methods of processing. However, there is need to investigate the effect of combined methods on the nutrients and anti-nutrients.
\end{abstract}

KEY WORDS: Dolichos lablab, proximate composition, processing, anti-nutrients

\section{INTRODUCTION}

The United Nations General Assembly declared the year 2016 as the International Year of Pulses (IYP). This was designed to raise public awareness of the nutritional value of legume plants in order to improve food and nutrition security. Dolichos lablab (Lablab purpureus) is a drought tolerant legume crop usually grown for human food, soil conservation and animal fodder. The crop can be incorporated into intercrop systems (Maass et al., 2010). This little known legume (Osman, 2007) is believed to have originated from Asia and was introduced to Africa in the eighth century (Deka \& Sarkar, 1990), Australia and America. The legume is known by different names across the world (Mortuza \& Tzen, 2009; Murphy \& Colucci, 1999). In Kenya it is referred to as Njahe (Kikuyu), Chabi (Meru) and Mbumbu or Nzavi among the Akamba community (Kinyua \& Kiplangat, 2012).
Dolichos lablab seeds, like other legumes are a valuable element of a healthy diet due to their content of protein, of high biological value. Additionally, they are a source of other valuable nutrients such as minerals and carbohydrates. They have the potential to contribute towards the alleviation of malnutrition and food insecurity due to adaptability, especially in the current climate inconsistencies (Maass et al., 2010). However, the nutritive value of this legume grain is pegged on nutrient content and the presence or absence of and the varying degrees of antinutrients such as tannins, phytates and trypsin inhibitors among others (Egounlety \& Aworh, 2003). For proper utilisation of Dolichos lablab, it is necessary to understand their nutritional quality considering anti-nutrients levels.

Legumes are normally processed before 
consumption. Different methods of processing have been used in enhancing the nutritional quality and mitigating the effects of inherent anti-nutritional factors. Common methods that have been employed for various legumes include thermal processing (Alagbaoso et al., 2016; Wang et al., 2010), fermentation (Egounlety \& Aworh, 2003) soaking and germination (Soetan \& Oyewole, 2009).
As one of the crops that are categorized as orphan or lost crops of Africa, Dolichos lablab has received minimal research attention and its production has remained at subsistence level for human consumption and as a cover crop in Kenya. In order to enhance production and utilization of Dolichos lablab, research on the effects of different processing methods on nutrients and anti-nutritional factors is required.

\section{OBJECTIVE}

This study aimed at investigating the effects of soaking, cooking and germination on the nutrients and antinutrient content of Dolichos lablab (KAT/DL-2) bean variety commonly utilised in Kenya.

\section{MATERIALS AND METHODS}

\section{Sourcing of samples and preparation}

Dolichos lablab bean (Lablab purpureus) variety KAT/DL-2 were sourced from Kenya Agricultural Livestock and Research Organisation (KALRO), Katumani Dryland Research Station. The samples were sorted to remove foreign materials and immature seeds. Raw bean samples were ground and placed into plastic bags then stored at $4^{\circ} \mathrm{C}$. Other samples were rinsed then placed in perforated plastic bags and cooked in a water bath maintained at $97^{\circ} \mathrm{C}$ until they were soft (softness was tested by pressing between the fingers). Another set of Dolichos lablab beans $(100 \mathrm{~g})$ was soaked in distilled water $(1: 10 \mathrm{w} / \mathrm{v})$, according to Ramakrishna et al. (2006) at room temperature for $6 \mathrm{hr}, 12 \mathrm{hr}$ and $24 \mathrm{hr}$. Some other samples were soaked for $24 \mathrm{~h}$ before being allowed to germinate on paper towels for $48 \mathrm{hr}$.

\section{Proximate composition analysis and energy values}

The proximate composition of the Dolichos lablab seeds was determined according to the procedures of AOAC (2000). Crude protein was calculated using the factor of 6.25 . The carbohydrates in the samples were estimated by difference, by subtracting the sum of dry matter percentage of crude protein, crude fats and crude ash and moisture from 100. The sample calorific values were estimated [in $\mathrm{kcal} / \mathrm{g}$ ] by multiplying the percentages of crude protein, crude fat and carbohydrates using the Atwater specific factors as adopted by the Food and Agriculture Organisation (WHO/FAO, 2002) for legume grains: proteins (3.47), fats (8.37) and carbohydrates (4.07).

\section{Determination of phytic acid}

Determination of phytic acid was done according to Clydesdale (1982). About $0.5 \mathrm{~g}$ of accurately weighed sample was extracted with $3 \% \mathrm{H}_{2} \mathrm{SO}_{4}$ and the phytic acid precipitated with ferric chloride, followed by conversion to sodium phytate that was then separated on a C-18 Column of HPLC using a Refractive Index Detector. A standard solution containing $10 \mathrm{mg} / \mathrm{ml}$ of sodium phytate (Inositol hexaphosphoric acid) was used for the standard curve work.

\section{Determination of tannins}

Tannins were extracted from about $0.2 \mathrm{~g}$ of accurately weighed sample using acidic methanol as described by Prince and Scoyoc (1978). The resulting extract was made up to $25 \mathrm{~mL}$. One millilitre of the extract was placed in a test tube and $5 \mathrm{~mL}$ of freshly prepared vanillin- $\mathrm{HCl}$ reagent was added slowly while mixing and the colour developed was read at $500 \mathrm{~nm}$. The results were quantified against a Catechin standard curve. The results were expressed as $\mathrm{mg} / 100 \mathrm{~g}$ catechin, dry weight. 


\section{Determination of trypsin inhibitor activity}

The Trypsin inhibitor activity (TIA) was determined according to Kakade et al. (1974) with modifications. Some $50 \mathrm{~mL}$ of $0.01 \mathrm{~mol} / \mathrm{L}$ of $\mathrm{NaOH}$ was used to extract one gram of the sample flour for $1.5 \mathrm{hr}$. Portions (0.6, 1.0, 1.4 and $1.8 \mathrm{~mL})$ of the suspension were pipetted into duplicate sets of test tubes and adjusted to $2.0 \mathrm{~mL}$ with water. The blank sample tube did not have any $\mathrm{NaOH}$. Then $2 \mathrm{~mL}$ of trypsin solution (4 mg trypsin in $200 \mathrm{~mL}$ $0.001 \mathrm{~mol} / \mathrm{L} \mathrm{HCl}$ ) was added to each tube before placing in a water bath maintained at $37{ }^{\circ} \mathrm{C}$. To each tube, $5 \mathrm{~mL}$ of N-benzoyl-DL-arginine $\mathrm{p}$ nitroanilide hydrochloride (BAPA) solution was added. The solution (40 mg BAPA in $100 \mathrm{~mL}$ water with $1 \mathrm{~mL}$ dimethyl sulphoxide) had been previously warmed to $37^{\circ} \mathrm{C}$. The reaction was terminated after 10 minutes by adding $1 \mathrm{~mL}$ of acetic acid. The absorbance of the solution was measured at $410 \mathrm{~nm}$ wavelength against a reagent blank. The trypsin inhibitory activity was calculated using the formula $\mathrm{TIA}=[(2.632 \times \mathrm{D} \times \mathrm{A} 1) / \mathrm{S}] \mathrm{mg}$ pure trypsin inhibitor/g sample, where A1 = change in absorbance due to trypsin inhibition $/ \mathrm{mL}$ diluted sample extract, $\mathrm{D}=$ dilution factor and $\mathrm{S}=$ weight of sample $(\mathrm{g})$.

\section{STATISTICAL ANALYSIS}

The analysis was carried out in three replicates for all determinations. The mean and standard deviation of means were calculated. The data were analysed by one- way analysis of variance (ANOVA). A multiple comparison procedure of the treatment means was performed by Duncan's new multiple range test (Duncan, 1955). Significance of the differences was defined as $P<0.05$

\section{RESULTS AND DISCUSSION}

Table 1 shows the proximate composition in raw and processed Dolichos lablab beans. The percent raw protein content $(24.36 \%)$ compared to those obtained for Dolichos beans in Tamil Nadu, India (Kamatchi et al., 2010). However, they were higher than those obtained in other areas (Ragab et al., 2012; Subagio, 2006) . There was significant $(\mathrm{P}<0.05)$ increase in percent protein content in germinated lablab beans. Heat treatment and soaking decreased the protein content.

Table 1: Effect of processing on Proximate composition (g $100 \mathrm{~g}$ dry weight) of Dolichos lablab

\begin{tabular}{|l|l|l|l|l|l|l|}
\hline \multicolumn{9}{|c|}{ Treatments } \\
\hline Proximate composition & Raw & Cooked & $\begin{array}{l}\text { soaked } \\
\text { 6hrs }\end{array}$ & $\begin{array}{l}\text { soaked } \\
12 \text { hrs }\end{array}$ & $\begin{array}{l}\text { Soaked- } \\
24 h r s\end{array}$ & $\begin{array}{l}\text { Germinated } \\
\text { Proteins }\end{array}$ \\
\hline Ash & $24.36^{\mathrm{c}} \pm_{0.20}$ & $22.20^{\mathrm{a}} \pm_{0.30}$ & $23.76^{\mathrm{b}} \pm_{0.10}$ & $22.78^{\mathrm{a}} \pm_{0.11}$ & $22.55^{\mathrm{a}} \pm_{0.49}$ & $26.38^{\mathrm{d}} \pm_{0.47}$ \\
\hline Fats & $4.14^{\mathrm{a}}{ }_{ \pm 0.27}$ & $4.03^{\mathrm{a}}{ }_{ \pm 0.10}$ & $4.15^{\mathrm{a}}{ }_{ \pm 0.07}$ & $3.97^{\mathrm{a}}{ }_{ \pm 0.22}$ & $4.08^{\mathrm{a}}{ }_{ \pm 0.21}$ & $3.85^{\mathrm{a}}{ }_{ \pm 0.17}$ \\
\hline Carbohydrates & $2.59^{\mathrm{e}} \pm_{0.15}$ & $2.19^{\mathrm{d}} \pm_{0.08}$ & $1.88^{\mathrm{c}} \pm_{0.01}$ & $1.87^{\mathrm{c}} \pm_{0.06}$ & $1.64^{\mathrm{b}} \pm_{0.10}$ & $1.36^{\mathrm{a}} \pm_{0.11}$ \\
\hline Energy kcal/g & $60.79^{\mathrm{a}} \pm_{0.20}$ & $64.51^{\mathrm{e}} \pm_{0.43}$ & $61.68^{\mathrm{b}} \pm_{0.14}$ & $63.55^{\mathrm{cd}} \pm_{0.24}$ & $63.04^{\mathrm{c}} \pm_{0.19}$ & $63.68^{\mathrm{d}} \pm_{0.48}$ \\
\hline
\end{tabular}

Means with different superscripts within a row indicate significant differences $\mathrm{P}<0.05$

Carbohydrates calculated by difference (100- (crude proteins + ash + fats $)$ ) 
There was a $2 \%$ protein content increase recorded for germinated beans. Similar results were obtained by Borijindakul \& Phimolsiripol (2013) who reported an increase of $2.7 \%$ after germinating lablab beans, while Ghavidel \& Prakash (2007) also reported an increasing pattern of protein content upon germination of other legumes. (Sattar et al., 1989) suggests that this trend may not be an increase in true protein, but elevation of non-protein nitrogen values. However, other studies have attributed this increase to hydrolysis and metabolism of storage proteins, carbohydrates and fats (Rumiyati, James, \& Jayasena, 2012). Heat processing and soaking has been reported to decrease protein content in legumes (Haruna \& Bichi, 2015), generally. This could be ascribed to leaching of the soluble or the proteineous parts into the soaking and cooking water.

The research recorded ash content of $4.14 \%$ for the raw samples (Table 1) similar to (4.48-3.97\%) reported by Kamatchi et al. (2010). There was no significant difference $(p>0.5)$ in the ash values between treatments. Thus the treatments had no effect on ash content. Oluwole (2012) reported such relationship for raw, germinated and fermented flour samples. The ash content results are in line with the United States ash content (4.29 per 100 grams) of the lablab beans edible portion tabulated in the National Nutrient Database for Standard Reference, Release 20 (2007).

The results also indicate Dolichos beans have reasonable amounts of fats like other legumes (Pious \& Veerabahu, 2013; Megat et al., 2011). The fats content in raw beans ranged between 2.56 and $2.68 \%$. These values are comparable to other research findings on lablab beans(Chau et al., 1998; Kamatchi et al., 2010; Subagio, 2006). The fat decreased significantly upon subjection to cooking, soaking and germination. Contrasting for proteins, germination registered the highest decrease of the fat content. This observation is in agreement with other scientific findings that have observed that processing techniques such as cooking, soaking and germination lower the fat content (D'souza, 2013).

The carbohydrates values were between 60.79$63.68 \%$ and those for energy $353.7-361.4 \mathrm{kcal} / 100 \mathrm{~g}$. These values agree with the findings of Kamatchi et al. (2010). There was a significant increase in carbohydrates content for all cooked and soaked lablab beans. Similar findings were reported for lablab beans (D'souza, 2013; Osman, 2007), and Phaseolus vulgaris (Nakitto et al., 2015). An increase in carbohydrates may not translate to increased kilocalories since protein and fat content have to be considered in the energy calculations.

\section{Table 2: Effect of processing on anti-nutritional factors (tannins, TIA and phytates, mg/100g)}

\begin{tabular}{lllllll}
\hline & Raw & Cooked & soaked_6hrs & soaked_12hrs & Soaked-24hrs & Germinated \\
\hline Tannins $m g / 100 g$ & $330.3^{\mathrm{d}} \pm 7$ & $208.1^{\mathrm{a}} \pm 6.2$ & $333^{\mathrm{d}} \pm 8.1$ & $325.5^{\mathrm{d}} \pm 5.72$ & $262.7^{\mathrm{c}} \pm 8.24$ & $226.5^{\mathrm{b}} \pm 10$ \\
TIA $\mathrm{mg} / 100 \mathrm{~g}$ & $1.30^{\mathrm{c}} \pm 0.1$ & $0.15^{\mathrm{a}} \pm 0.1$ & $0.85^{\mathrm{b}} \pm 0.1$ & $0.72^{\mathrm{b}} \pm 0.08$ & $0.88^{\mathrm{b}} \pm 0.07$ & $0.83^{\mathrm{b}} \pm 0.1$ \\
$\begin{array}{l}\text { Phytates } \\
\text { mg/lo0g }\end{array}$ & $723.6^{\mathrm{f}} \pm 7.01$ & $388.6^{\mathrm{a}} \pm 3.2$ & $673^{\mathrm{e}} \pm 7.3$ & $562.5^{\mathrm{c}} \pm 2.11$ & $582.4^{\mathrm{d}} \pm 3.3$ & $473.5^{\mathrm{b}} \pm 5.8$ \\
\hline
\end{tabular}

Different superscripts within a row indicate significant differences, $\mathrm{P}<0.05$.

Raw lablab beans had tannin contents of $330.3 \pm 7$ $\mathrm{mg} / 100 \mathrm{~g}$ (Table 2), which significantly reduced 100 -fold when the beans were cooked. Soaking the beans resulted in a significant decrease in the tannin contents after $24 \mathrm{hr}$. However, there was no significant change in the tannin content at $6 \mathrm{~h}$ of soaking which could be attributed to low hydration capacity of the beans. These findings are in agreement with other similar works of Nakitto et al. (2015) for common beans, Sharma et al. (2013) for soybeans and in Dolichos beans (Osman, 2007). However, there was significant reduction of phytates and trypsin inhibitory activity (TIU) across all the treatments. Other works have realised such comparable results for Soybean and Cow pea (Egounlety \& Aworh, 2003), Jack beans (Doss et al., 
2011) and common beans (Fernandes et al., 2010). Cooking realised the highest decrease for all antinutritional factors. Physical and chemical methods are normally employed to reduce or remove the antinutritional factors enhancing the nutritional value of the legume beans (Soetan \& Oyewole, 2009). Other methods that have been employed to reduce antinutritional factors in legumes include fermentation and enzymatic treatments.

\section{CONCLUSION}

Different methods of processing can be used to reduce levels of anti-nutrients without adversely affecting the proximate composition of the beans. Germination was found to increase the protein content, while cooking significantly reduced the anti-nutritional factors. Cooking was therefore found to be the most effective method of eliminating anti-nutritional factors in the beans, thus making the beans safe for consumption However, there is need to investigate the effect of combined methods and explore the use of enzymatic

\section{ACKNOWLEDGMENT}

The authors acknowledge the Kenya Agricultural Livestock and Research Organisation (KALRO), Katumani Dryland Research Station through Dr. Kamau who provided the experimental samples. This research work was funded by the Germany academic exchange service (DAAD) and the International Foundation of Science (IFS).

\section{REFERENCES}

Alagbaoso, S. O., Nwosu, J. N., Agunwa, I. M., Njoku, N. E., Akajiaku, L. O., \& Eluchie, C. N. (2016). Effect of Some Thermal Processing Techniques on the Anti- nutritional Factors of Canavalia plagiosperma Piper Seeds. American Journal of Food Science and Technology, 2016, 4(1), 7-13. https://doi.org/10.12691/ajfst-4-1-2

Borijindakul, L., \& Phimolsiripol, Y. (2013). Physicochemical and functional properties of starch and germinated flours from Dolichos lablab. Food and Applied Bioscience Journal, 1(2), 69-80.

Chau, C. F., Cheung, P. C. K., \& Wong, Y. . S. (1998). Chemical composition of three underutilized legume seeds grown in China. Food Chemistry, 61(4), 505-509. https://doi.org/10.1016/S0308-8146(97)00094-0

D'souza, M. . (2013). Effect of traditional processing methods on nutritional quality of fied bean. Advances in Bioresearch, 4(3), 29-33.

Deka, R. K., \& Sarkar, C. R. (1990). Nutrient composition and antinutritional factors of Dolichos lablab L. seeds. Food Chemistry, 38(, 4, 239-246.

Doss, A., Pugalenthi, M., Vadivel, V. G., Subhashini, G., \& Subash, A. R. (2011). Effects of processing technique on the nutritional composition and antinutrients content of under - utilized food legume. Food Chemistry, 18(3), 965-970.

Duncan, B. D. (1955). Multiple Range and Multiple F Tests. Biometrics, 11(1), 1-42.

Egounlety, M., \& Aworh, O. . (2003). Effect of soaking, dehulling, cooking and fermentation with Rhizopus oligosporus on the oligosaccharides, trypsin inhibitor, phytic acid and tannins of soybean (Glycine max Merr.), cowpea (Vigna unguiculata L. Walp) and groundbean (Macrotyloma geocarpa Ha. Journal of Food Engineering, 56, 249-254.

Fernandes, A. C., Nishida, W., \& Da Costa Proença, R. P. (2010). Influence of soaking on the nutritional quality of common beans (Phaseolus vulgaris L.) cooked with or without the soaking water: A review. International Journal of Food Science and Technology, 45(11), 2209-2218. https://doi.org/10.1111/j.1365-2621.2010.02395.x

Ghavidel, R. A., \& Prakash, J. (2007). The impact of germination and dehulling on nutrients, antinutrients, in vitro iron and calcium bioavailability and in vitro starch and protein digestibility of some legume seeds. LWT - Food Science and Technology, 40(7), 1292-1299. https://doi.org/10.1016/j.lwt.2006.08.002

Haruna, M., \& Bichi, A. H. (2015). Effect of different heat processing methods on the proximate composition of Piliostegma reticulatum seed meal, $8(1), 115-122$.

Kakade, M., Rackis, J., McGhee, J., \& Puski, G. (1974). Determination of trypsin inhibitor activity of soy products: a 
collaborative analysis of an improved procedure. Cereal Chem, 51, 376-382. Retrieved from http:// naldc.nal.usda.gov/naldc/catalog.xhtml?id=31302

Kamatchi, K. B., Tresina, S. P., Mohan, V. R., \& Vadivel, V. (2010). Nutrient and Chemical Evaluation of Raw Seeds of Five Varieties of Lablab purpureus ( L .) Sweet. Advances in Bioresearch, 1(1), 44-53.

Kinyua, G. M., \& Kiplangat, K. O. (2012). Dolichos (lablab purpureus. LSWEET) bean improvement using mutation and biotechnological techniques. Nairobi: Danste Agencies.

Maass, B. L., Knox, M. R., Venkatesha, S. C., Tolera Angessa, T., Ramme, S., Pengelly, B. C., ... Angessa, T. T. (2010). Lablab purpureus-A Crop Lost for Africa? Tropical Plant Biol, 3, 123-135. https://doi.org/10.1007/s12042010-9046-1

Megat, R. M. R., Noraliza, C. W., Azrina, A., \& Zulkhairi, A. (2011). Nutritional changes in germinated legumes and rice varieties. International Food Research Journal, 18(2), 705-713.

Mortuza, M. G., \& Tzen, J. T. (2009). Physicochemical and functional properties of ten cultivars of seem ( Lablab purpureus L.), an underexploited bean in Bangladesh. Journal of the Science of Food and Agriculture, 89(8), 12771283. https://doi.org/10.1002/jsfa.3583

Mostafa, M. M., Rahma, E. H., \& Rady, A. H. (1987). Chemical and nutritional changes in soybean during germination. Food Chemistry, 23(4), 257-275. https://doi.org/10.1016/0308-8146(87)90113-0

Murphy, A. M., \& Colucci, P. E. (1999). A tropical forage solution to poor quality ruminant diets: A review of Lablab purpureus. Livestock Research for Rural Development, 11(2), 16.

Nakitto, A. M., Muyonga, J. H., \& Nakimbugwe, D. (2015). Effects of combined traditional processing methods on the nutritional quality of beans. Food Science \& Nutrition, 3(3), 233-241. https://doi.org/10.1002/fsn3.209

Oluwole, S. I. (2012). Influence of germination and fermentation on chemical composition, protein quality and physical properties of wheat flour (Triticum aestivum). Journal of Cereals and Oil Seeds, 3(3), 35-47. https:// doi.org/10.5897/JCO12.015

Osman, M. A. (2007). effectof different processing methods on nutrient composition, antinutritional factors and invitro protein digestibility of Dolichos Lablab bean (Lablab purpureus (L)Sweet). Pakistan Journal of Nutrition, 6(4), 299 -303 .

Pious, S. T., \& Veerabahu, R. M. (2013). Assessment of nutritional and antinutritional potential of underutilized legumes of the genus Mucuna. Tropical and Subtropical A groecosystems, 16, 155-169.

Prince ML, Van Scoyoc S, B. L. (1978). Critical evaluation of the vanillin reaction as an assay for tannin in sorghum grain. Agric. Food Chem, (26), 1214-1218.

Ragab, H. I., Ati, K. A. A., Kijora, C., \& Ibrahim, S. (2012). Effect of Different Levels of the Processed Lablab purpureus Seeds on Laying Performance, Egg Quality and Serum Parameters. International Journal of Poultry Science $1,11(2), 131-137$.

Ramakrishna, V., Rani, P. J., \& Rao, P. R. (2006). Anti-Nutritional Factors During Germination in Indian Bean ( Dolichos lablab L .) Seeds. World Journal of Dairy \& Food Sciences, 1(1), 06-11.

Rumiyati, James, A. P., \& Jayasena, V. (2012). Effect of Germination on the Nutritional and Protein Profile of Australian Sweet Lupin (Lupinus angustifolius L.). Food and Nutrition Sciences, 3, 621-626. https://doi.org/10.4236/ fns.2012.35085

Sattar, A., Durrani, S. K., Mahmood, F., Ahmad, A., \& Khan, I. (1989). Effect of soaking and germination temperatures on selected nutrients and antinutrients of mungbean. Food Chemistry, 34(2), 111-120. https://doi.org/10.1016/0308 -8146(89)90079-4

Sharma, S., Goyal, R., \& Barwal, S. (2013). Domestic processing effects on physicochemical, nutritional and antinutritional attributes in soybean (Glycine max L. Merill). International Food Research Journal, 20(6), 3203-3209.

Soetan, K. O., \& Oyewole, O. E. (2009). The need for adequate processing to reduce the anti- nutritional factors in plants used as human foods and animal feeds: A review. African Journal of Food Science, 3(9), 223-232. Retrieved from http://www.academicjournals.org/AJFS

Subagio, A. (2006). Characterization of hyacinth bean ( Lablab purpureus ( L .) sweet ) seeds from Indonesia and their protein isolate. Food Chemistry, 95(1), 65-70. https://doi.org/10.1016/j.foodchem.2004.12.042

Wang, N., Hatcher, D. W., Tyler, R. T., Toews, R., \& Gawalko, E. J. (2010). Effect of cooking on the composition of beans (Phaseolus vulgaris L .) and chickpeas ( Cicer arietinum L .) q. Food Research International, 43(2), 589-594. https://doi.org/10.1016/j.foodres.2009.07.012

WHO/FAO. (2002). Food energy-methods of analysis and conversion. FAO Food and Nutrition Paper. https://doi.org/ ISSN 0254-4725 